\title{
A Truly Co-operative Venture: The Case of Co-operative Food
}

\author{
Bob Doherty*
}

\begin{abstract}
Civil society has responded to the predicament of marginalised producers by the rapid emergence of the fair trade market both within the UK and internationally.

Co-operative Food is part of a larger group of diverse businesses from travel to The Co-operative Bank. The Co-op is consumer owned and democratically controlled (one member one vote) by its members, ordinary shoppers.

Co-operative Food's success in mainstreaming fair trade demonstrates the important role played by social resources in ethical relationship marketing.
\end{abstract}

Keywords: Co-operative Food Fair Trade; Co-op Own Label; Corporate Social Responsibility; Ethics; Global Trade; Global Markets; The Case of Co-operative Food

\section{Introduction}

Civil society has responded to the predicament of marginalised producers by the rapid emergence of the FT market both within the UK and internationally (Barratt Brown, 1993; Crane and Matten, 2004; Lowe and Davenport 2005a). The Fairtrade Mark is now recognised by $52 \%$ of the population (Fairtrade Foundation 2006) and there are now over 2,500 retail and catering products carrying the Fairtrade Mark (Fairtrade Foundation 2006). According to Teather (2006) global sales of FT marked goods grew by more than a third to $£ 758$ million in 2005 . The UK market alone has grown by $46 \%$ and now totals £290m (Fairtrade Foundation 2006), Teather (2006) argues that the involvement of major retailers is key to this growth. One such retailer is Co-operative Food (CF).

$\square$ CF is part of a larger group of diverse businesses from travel to The Co-operative Bank. CF is different from most other UK retailers; it was founded in 1844 on a set of co-operative values and principles that guide the organisation (Birchall 1994). The Co-op is consumer owned and democratically controlled (one member one vote) by its members,

\footnotetext{
* Lecturer, Liverpool Business School (r.doherty@1jmu.ac.uk)
} 
ordinary shoppers. CF is now responsible for 3,000 UK stores which are in the main convenience stores (between 1,000 -5,000 square in size). By contrast Tesco plc own 1380 Tesco branded stores in the UK retail market (Tesco 2006, pg.10). CF for many years has been recognised for its Responsible Retailing Strategy, the Co-op Brand product range has been one key way of communicating this strategy (The Co-op and Fairtrade Strategy Paper 2000, internal document). The CF during 1998 decided to embark upon a strategy to take fair trade out of the niche and into the mainstream (Co-op 2002). By 2006 the CF share of the UK grocery FT market is $25 \%$, in contrast to its share of the overall grocery market which is 6.1\% (AC Neilson 2006). Fairtrade sales at CF totalled $£ 22 \mathrm{~m}$ in 2006 and are forecasted to reach $£ 28 m$ by end of 2007 (Co-op 2007). It is also worth noting that $64 \%$ of Co-op shoppers are aware of FT compared to 52\% nationally (Co-op 2007).

However Lowe and Davenport (2005a, 2005b) warn that despite growing FT sales uncritical engagement with mainstream business risks absorption and dilution of the FT movement. This can lead to 'Clean-wash' which occurs when a company 'derives positive benefits from its association with the fair trade movement, however minimal its efforts to 'live' the values' (Murray and Raynolds, 2000:p68-69). Nicholls (2002) suggested that developing a FT offer can provide retailers with an example of good CSR (Corporate Social Responsibility) and a good commercial opportunity. Nicholls (2002) outlined the typology of retailer responses to ethical consumerism with the Fair trade agreement being identified as one of the pro-active options. According to Nicholls, CF is the best example of a retailer working with this strategy. Lowe and Davenport (2005a) appear to agree and in their analysis of retailer engagement with Fairtrade, the CF is described as a values-driven business (see Figure 1). The aim of this paper is to explain in more depth the degree of the CF's commitment to Fairtrade, with particular reference to the conversion of its own label block chocolate range to $100 \%$ FT sourced from Divine Chocolate Ltd (formerly The Day Chocolate Company), this company is $45 \%$ owned by Kuapa Kokoo Farmers Co-operative in Ghana. It is important to note, this paper is not a direct comparison between CF and other UK retailers.

Recently a number of authors have called for further research to increase our understanding of FT marketing in the mainstream (Golding and Peattie 2005, Hira \& Ferrie 2006 and Nicholls and Opal 2004); this paper is an example of such work. Overall this paper falls into several sections; firstly the methodology employed to investigate the case of CF is explained. Secondly, the research seeks to investigate the discourse associated with mainstreaming Fairtrade including; modes of entry for FT products in the mainstream, strategic responses to mainstreaming FT, 'Clean-wash', 'radical mainstreaming' and 'the Alternative High Street'. This section will also critically examine marketing literatures such as Relationship Marketing, social resources (Doherty and Meehan 2006) and the 'new dominant logic of marketing' (Vargo and Lusch 2004). In the third section, the case study of CF is investigated and particularly its partnership with Divine Chocolate Ltd. 
The paper concludes by proposing a set of characteristics for a values-driven business in the UK retail sector responding to FT. In addition CF's success in mainstreaming FT demonstrates the important role played by social resources in ethical relationship marketing. This shows that a successful FT marketing strategy in the UK mainstream retail sector based on the principles of trust and commitment can actually strengthen the original ethical interest of the FT venture and not undermine this as argued by Lowe and Davenport (2005b).

\section{Methodology}

Due to the fact that FT mainstreaming is a relatively recent phenomenon a number of key insights can be gained from focusing on specific case studies (Eisenhardt 1989, Yin 2003). The author provides a longitudinal case (19992006) of the UK retailer Co-operative Food (CF) and in particular its truly cooperative venture with the unique 100\% FT business, the Divine Chocolate Ltd (formerly The Day Chocolate Company).

The fieldwork data collection methods in this study include both participant and personal observations recorded in a series of reflexive research diaries. In addition seven formal face to face one hour long semi-structured interviews (recorded and transcribed to print) with a range of key informants were carried out. These influential parties include supermarket buyers, supermarket ethical trading managers, industry journalists etc, key personnel at Divine Chocolate Ltd and key opinion formers within the Fairtrade movement including Ian Bretman (Deputy Director at the Fairtrade Foundation). These interviews were carried out between March 2000 to June 2007. The familiarity of the author with the sector proved invaluable in gaining access to these key informants. Also interviews were overt with the option of confidentiality explained by initial formal letter; hence some informants are described by number.

The validity of the interpretations offered here are strengthened via triangulation using multiple methods and sources, thus ensuring greater rigour in the findings and conclusions (Askey and Knight 1999). In addition to this, to ensure construct validity as explained by Yin (2003), a number of key informants were also asked to review this article.

\section{Mainstreaming Fairtrade}

The first report of the Ethical Purchasing Index (Cowe \& Williams 2000) highlighted the existence of the 30:3 gap between opinion surveys about consumer interest in ethical issues such as FT and actual spending behaviour on FT products. A number of authors reported then on the problem of poor availability in mainstream distribution as a barrier to growth of FT brands (Nicholls 2002, Nicholls and Opal 2005, Ronchi 2001 and Strong 1997). This is a critical limit to FT growth bearing in mind the increasing percentage of the UK food retail sector represented by UK supermarkets. According to Mintel (1999), $43 \%$ of all chocolate confectionery sold in the UK is purchased via multiple supermarkets and this proportion was likely to increase. By 2006 this percentage share had risen to $50 \%$ 
(Mintel 2006). According to the author; FT products have entered the UK mainstream market via a number of entry routes including:

1. Branded Fairtrade products from 100\% Fairtrade companies such as Divine Chocolate Ltd and Cafedirect. All products from these companies carry the Fairtrade mark.

2. Branded Fairtrade products from manufacturers where part of their product portfolio is Fairtrade marked products e.g. Clipper Teas, Green and Blacks Chocolate (owned by Cadbury Schweppes), Percol Coffee Company, Fyffe's (one of the five largest global fresh produce distributors which supply's Tesco with own label bananas), Nestlé and Billingtons (Europe's leading supplier of unrefined cane sugar).

3. Multiple Retailer own labelled Fairtrade products supplied by own label supplier. These products sit on the shelf with branded Fairtrade products.

4. Own labelled Fairtrade products from retailers Marks and Spencer and Starbucks Coffee Company who only stock their own labelled products.

5. Joint labelled Fairtrade products where mainstream retailer and fairtrade company work together on joint brands e.g. the original Co-op Divine $45 \mathrm{~g}$ milk chocolate bar (launched in 2000). Thus far only Co-operative Food has chosen this route with Divine Chocolate Ltd.

The paper will now explore the case study of the retailer called Co-operative Food.

\section{Co-operative Food's (CF) Response to Fairtrade}

\subsection{Background}

$\mathrm{CF}$ is a UK convenience store retailer with 3,000 stores. According to $\mathrm{CF}$ there is a natural link between the co-operatives movements values and principals and the ethics behind FT (Co-op 2002).

$\square$ In 2002, CF was the first major retailer to stock the FT coffee brand Cafedirect. The Co-operative Group has a society has over 4 million members who are very supportive of FT (The Co-operative Group 2007). The CF's fair trade objectives in 1998 were to bring Fairtrade to the mainstream and be the UK's leading Fairtrade supermarket supporter (Co-op 2000). The aim was to integrate FT with the Co-op brand and develop a range of Co-op branded FT products. The strategy wherever possible was for these products to be supplied from recognised FT development organisations such as Divine Chocolate Ltd. Co-op brand is a $£ 1$ billion brand and was the first retailer own brand introduced over 150 years ago (Co-op 2000). A number of research reports show Co-op brand being associated with enviable consumer trust and strong attributes of honesty and openness (Financial Times 2007, National Consumer Council 2006). 
The NOP survey (2007) reported Co-op brand as the UK's most ethical brand with national Consumer Council (2006) judging Co-op to be the most trusted UK brand. This demonstrates the value of social and ethical commitments in developing trust via the Co-op brand. The Co-op brand may also provide Murphy et al (2007) with an example of connecting branding with trust. The Co-op brand in the year 2000 already accounted for $40 \%$ of Co-op sales. Co-op offered a substantial platform to the mainstream for FT. The Fairtrade achievements of the Co-op are listed as milestones in Table 1.

The initiatives outlined in table 1 illustrate the strength of the CF's ethical commitment towards FT. It is a pioneer in a number of areas taking first place launch position on a number of products and stocking FT products in all 3,000 stores. In 2002, CF also took the radical step of switching Co-op own label chocolate to $100 \% \mathrm{FT}$.

Table 1: Co-operative Food Fairtrade Milestones

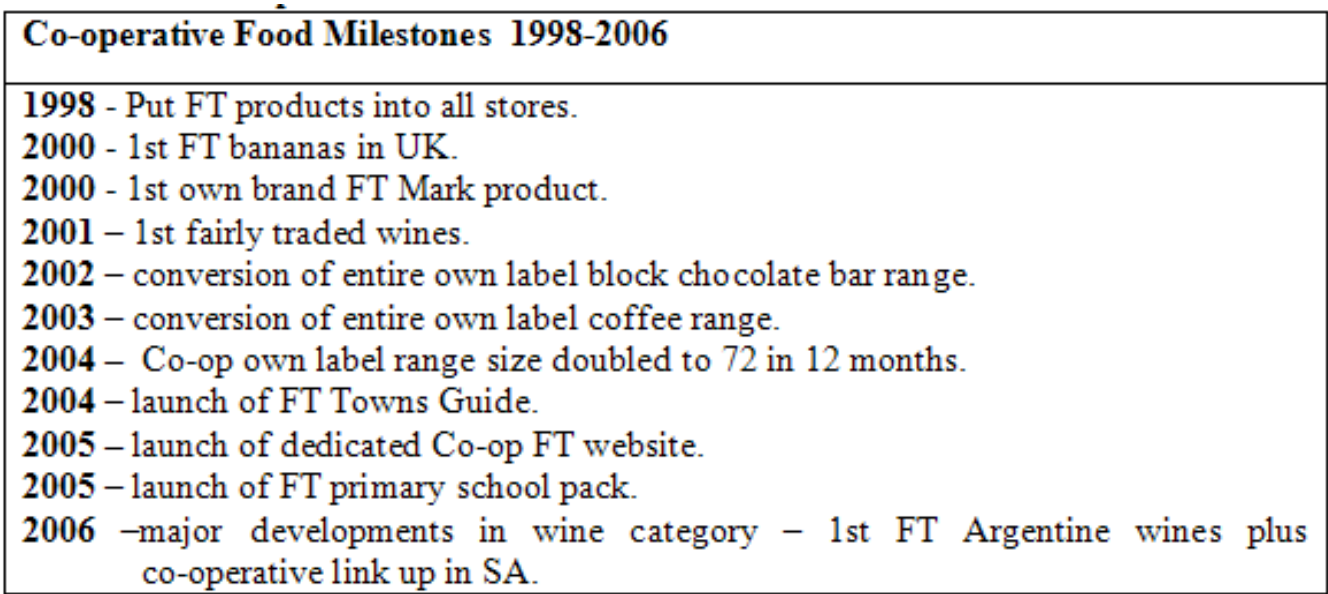

Source: Co-operative Food internal documents

\subsection{Conversion of Co-op Own Label Chocolate}

This paper is particularly interested in the own label chocolate conversion to $100 \%$ FT. In 2002, the Co-operative Food Retail Executive Committee decided to make a significant strategic move in FT by switching its entire own label block chocolate range to $100 \%$ FT sourced. At the time the Co-op own label block chocolate was supplied by Kraft Jacob Suchard and totalled $£ 1$ million in sales at retail value.

Brad Hill (CF Strategic Fairtrade Development Manager) explains:

$\square$ Kraft were offered the opportunity to move to FT as the incumbent supplier to the Co-op. We received a quick negative response from them (interview with Brad Hill, 2007) 
The category management teams were concerned with both the commercial risk and how the Co-op consumer would respond to a new range of block chocolate recipes from a new supplier. However CF decided to go ahead and partner with Divine Chocolate Ltd due to an existing relationship. Divine Chocolate's credibility and its co-operative links with Kuapa Kokooo in Ghana were also attractive to CF. This bold move led to a documentary screened in November 2002 on BBC News 24 about Fairtrade Chocolate, CF produced a campaign document in 2002 called 'The Chocolate Report' which discusses in depth the inequalities in the world trading system and how both FT consumption and lobbying the large multinationals to convert to FT can make a difference. Divine Chocolate organised a trip for commercial representatives from the $\mathrm{CF}$ to visit $\mathrm{KK}$ in Ghana and view the impact of Fairtrade. Brad Hill (CF Strategic Fairtrade Development Manager) who visited Ghana explains why the partnership with Divine Chocolate works:

$\square$ Divine Chocolate has strong credibility that you can trust and the links back to the producers are strong, from our point of view, the links back to the producers have always been a very strong part of our strategic message on Fairtrade (interview with Brad Hill, 2005).

This evidence appears to highlight the importance of connections with partners in the value chain and again the importance of trust and credibility in building relationships. Sales of the new Co-op Fairtrade Chocolate range outperformed the previous own label range by over $30 \%$ in the first year 2002/2003. This is compared to a decline in branded chocolate products of 15\% (Mintel 2003). Sales continue to grow and in 2006 retail sales of Co-op own label FT chocolate range are worth over $£ 4 \mathrm{~m}$ showing a $20 \%$ growth on 2005 (Co-op 2006). The Co-op own label block chocolate range now totals 13 products. According to $\mathrm{CF}$, the success of this mainstream FT chocolate venture resulted in the move to switch the entire Co-op own label range of coffee to Fairtrade (Co-op 2003).

Due to their partnership relationship with Divine Chocolate, CF are the FT licensee for their own label FT chocolate range. This means CF have signed a contract committing themselves to the FT standards and processes which in addition to paying a license fee also includes financial support for producer support and development. This is made possible due to Divine's processes, which commit the $100 \%$ FT company to pay not only the FT license fee on their entire turnover but also a producer support and development fee of $1.4 \%$ on all cocoa purchased. This development fee is within the price CF pay Divine Chocolate for the product. This position by $\mathrm{CF}$ is further evidence of its ethical commitment to FT.

Despite the pressure for shelf-space within stores, CF agreed not to replace Divine Chocolates existing brands of Divine and Dubble Fairtrade chocolate with their new Co-op range, but for both brands to be available in CF stores. David Croft (former Head of FT at CF) explains;

$\square$ 'It's important that retailers do not let own label FT products cannibalise sales of existing FT brands' (McAllister 2004, pg. 42-47). 
The success of Divine Chocolate's partnership with CF (see above) has provided the business case for $\mathrm{CF}$ to continue with its Fairtrade own label programme.

David Croft (Former Head of Co-op Brand) explains:

'The relationship is a real partnership with Divine Chocolate. We both have a shared vision and a shared ownership perspective of key issues. Discussions are easier and there is a greater degree of flexibility in the relationship in comparison to the major players, which actually means the relationship between the Co-op, and Divine is stronger. For example the relationship with the major players is based on the need to make more money. With Divine it is a different level of relationship, of course there is a need to make money but what we are doing together is much broader than just making money' (interview with David Croft, 2005)

The value of this relationship between $\mathrm{CF}$ and Divine Chocolate is also demonstrated by the willingness of $\mathrm{CF}$ to discuss flexible payment terms at critical stock flow periods, shared promotional costs, no requirement to pay listing fees and the investment of $\mathrm{CF}$ in Fairtrade marketing communications (personal diary extracts). This is in contrast to the practices highlighted by authors who are critical of the way supermarkets treat suppliers (Blythman 2004 and Lawrence 2004). In fact Blythman (2006) agrees and proposes that $\mathrm{CF}$ exhibit a non-exploitative and developmental approach to FT (interview on BBC Money Programme 2006). This approach appears to support the work of Murphy et al (2007) and shows the value of both diligence and commitment by the Co-op in sustaining relationships.

Between 2002-2005 (post launch of this own label FT chocolate range), the CF promotional support package for FT which included national TV advertising totalled over £3million. CF has managed to secure mainstream media coverage, presented in Table 2.

CF has also given up specific merchandising space in shops to FT, called Responsible retailing bays with associated point of sale. This increases the number of product facings in store and is termed dual distribution. From the evidence it could be argued CF is an exemplar in how to communicate the human element of Fairtrade, highlighted by Strong $(1996,1997)$ as a key challenge for the FT movement. CF's marketing communications illustrated by the 'chocolate report' have focused on the transformative message of FT and not just the price and quality message, which Lowe and Davenport (2005b) argue is a danger of being in the mainstream.

Brad Hill (CF Strategic Fairtrade Development Manager) explains:

'We are convinced that our funded marketing activity on Fairtrade has assisted in mainstreaming fair trade and as probably been a key factor in stimulating other retailers such as Tescos to stock Fairtrade lines' (interview with Brad Hill, 2005). 
Table 2: Co-operative Food Fairtrade Media Highlights

\begin{tabular}{|c|c|c|}
\hline Media Type & Media types & Values \\
\hline 2002 & $\begin{array}{l}\text { BBC News } 24 \text { TV documentary on the } \\
\text { Cocoa supply chain } \\
\text { TV chocolate advertising on UK } \\
\text { Independent Television } \\
\text { Plus ' } 484 \text { additional media items }\end{array}$ & $\begin{array}{l}2002 \text { activity is valued at } \\
\text { £2million and reaching a } \\
\text { potential audience of } 95 \text { million }\end{array}$ \\
\hline 2003 & $\begin{array}{l}547 \text { Fairtrade media items. Two most } \\
\text { valuable pieces included TV features } \\
\text { on UK GMTV news during Fairtrade } \\
\text { Fortnight campaign. }\end{array}$ & 2003 activity valued at $£ 695 \mathrm{k}$ \\
\hline 2004 & 647 media items & $\begin{array}{l}\text { Public relations value of } £ 1.4 \\
\text { million }\end{array}$ \\
\hline 2005 & 416 media items & Public relations value of $f 515 \mathrm{k}$ \\
\hline 2006 & $\begin{array}{l}\text { Highlights included television feature } \\
\text { on BBC Money programme } \\
\text { Kuapa Kokoo and Co-op television } \\
\text { feature on ITV Tonight with Trevor } \\
\text { McDonald }\end{array}$ & $£ 1.9 \mathrm{~m}$ Public Relations value \\
\hline 2007 & $\begin{array}{l}\text { TV features on both GMTV and } \\
\text { Channel 4. Plus Guardian and } \\
\text { Observer features on stocking of } \\
\text { Fairtrade Bananas in all Co-op stores }\end{array}$ & $£ 1.1 \mathrm{~m}$ public relations value \\
\hline
\end{tabular}

Source: Co-op Fairtrade Marketing Review 2007, internal document

David Smith (Trading Manager) at Booths Supermarkets agrees and explains:

$\square$ 'The one company who has had the most impact on Fairtrade in the $U K$ is the Co-op. Their national advertising in magazines and television, also the Co-op coming in on their own label, has created Fairtrade awareness there's no doubt about that' (interview David Smith, 2005).

The CF's truly co-operative venture with Divine Chocolate has been identified as key in the success of this communications strategy.

David Croft, (Former Head of Co-op Brand \& Technical Affairs at CF), explains:

$\square$ 'Without Divine, CF Fairtrade chocolate communications strategy would have been more piecemeal and more disparate; the partnership has resulted in greater Co-op brand equity. This has been achieved through a strong relationship with Divine Chocolate and its amazing 'story'. We have used this story in marketing messages, which screams credibility, which is an incredible asset. Links back to the producers have always been a very strong part of our strategic message on 
Fairtrade. I think without Divine's input it would have been difficult and certainly would have taken a lot longer to make some of those arguments to the mainstream part of the business shall we say' (interview with David Croft, 2005).

This evidence of a communications strategy which places ethical and social commitments to FT as the key message, is further support for the concept of social resources proposed by Doherty and Meehan (2006). The findings of this research also provide a case to support the importance of ethics in RM. It is clear the links to Kuapa Kokoo farmers in this FT relationship are central in developing the FT values of the Co-op brand.

This message has also been important with internal staff at CF, Terry Hudghton also (Head of Co-op brand 1998-2002) explains:

$\square$ 'Working with the buying team on the own label development helped Divine Chocolate to communicate the FT message to our buying team, thus facilitating a deeper understanding of FT' (interview with Terry Hudghton 2001).

This may explain how some of the commercial pressures with the category management team were overcome.

Stephen Newbold (Category Confectionery buyer at CF) agrees and also explains:

$\square$ 'Our work with Divine Chocolate on own label Fairtrade chocolate has certainly pressed us to seek as much assurance from branded and non branded chocolate manufacturers about the fairness in their own supply chains' (interview with Stephen Newbold, 2005).

From a UK supermarket audit in 2006, CF stocked 151 FT Fairtrade products. In contrast an equivalent sized Tesco Express store stocked on average only three FT products. This illustrates the depth of distribution of FT products in CF stores and therefore its own commitment to FT. CF Fairtrade own label chocolate is stocked in all 3,000 stores; this addresses the concerns expressed by those authors who identified poor availability in the mainstream as a barrier to FT growth (Nicholls 2002, Nicholls and Opal 2005, Ronchi 2001, Strong 1997). This is also most advantageous in raising the awareness of FT bearing in mind that $43 \%$ of the public hear of FT while shopping (Fairtrade Foundation 2005).

Ian Bretman (Deputy Director of the Fairtrade Foundation) explains:

'The CF's work on FT is even more impressive if you bear in mind both their size and consumer demographic. Larger retailers have more capacity, also CF have managed to link-up senior management policy on FT with internal marketing and buying functions' (interview with Ian Bretman, 2007). 
The depth of FT product distribution and the level of FT awareness at all levels within $\mathrm{CF}$ again highlights their strong ethical and social commitment to FT.

\subsection{CF and 'The Alternative High Street'}

As noted in table 2, CF has not limited itself to just selling FT products. Both its launch of information packs on Fairtrade Towns and it Fairtrade school pack for primary schools are both focused on the transformative message of FT. In addition its campaign to lobby branded chocolate manufacturers is another example of CF creating innovative approaches to bring consumers and producers together to initiate change. Also CF's decision to switch all its block chocolate to FT was recognised in an Early Day Motion (EDM) in the UK House of Commons, which was signed by 40 MP's. These are examples of 'the Alternative High Street' where the $\mathrm{CF}$ is working to protect the integrity of Fairtrade.

Brad Hill explains that:

$\square$ 'Our work with Fairtrade Towns and schools is not based on sales and the information packs we have produced are not commercial documents, this demonstrates the depth of our commitment to Fairtrade' (interview with Brad Hill, 2007).

The Co-op membership also have a dedicated person called the Fairtrade work stream leader that works with Brad Hill and his team to organise educational initiatives such as Fairtrade conferences, awareness raising events in CF stores and political lobbying of MP's. The activity of CF shows how companies can leverage their social resources in the mainstream to create significant FT sales growth. This longtitudinal case study also demonstrates the consistency of behaviour over a period of time by $\mathrm{CF}$ in response to FT. It is interesting to note that recently a number of retailers have responded to FT.

Ian Bretman (Deputy Director of the Fairtrade Foundation) explains:

'There are now definite echo's of the Co-op's FT work at Marks \& Spencer's. $M \& S$ due to the companies re-positioning to Your M\&S have launched The M\&S PLAN A, which is values based' (interview with Ian Bretman, 2007).

The paper will now conclude by explaining the characteristics of a values driven retailer in response to FT.

\section{Conclusion}

With regard to its Fairtrade response, CF is proposed by Lowe and Davenport (2005a) as a values driven business. From this longitudinal case study a number of 'characteristics' of a values driven retail response to fair trade have been identified. 
The author has applied the concepts of social resources and ethical relationship marketing to provide a framework for this proposition.

With regard to the social resources of (1) ethical and social commitments and (2) structural connections with partners in the value chain it is clear that CF have:

- taken a pro-active approach to developing direct supply relationships with 'radical mainstreaming' companies such as Divine Chocolate and their producers Kuapa Kokoo;

- embedding the Fairtrade standards into the business by either paying for the Fairtrade license fee or building the fee into negotiations;

- conversion of entire own label ranges to $100 \%$ Fairtrade with associated commercial risks;

- sustained and consistent investment in marketing communications to raise Fairtrade awareness and lobby for change in industry practices;

- marketing communications focused on producer relationships and the transformative message of FT;

- with reference to chocolate, agreement not to cannibalise existing branded Fairtrade products;

- commitment to 'the Alternative High Street' where social change is the main focus. CF's commitment to campaigning demonstrates its focus on the message of transformative change.

FT is only as good as the criteria on which it is based and therefore investment in developing depth to the criteria is essential to avoid the threat of 'Clean-wash' and 'Fair Trade Lite'. The characteristics identified in this paper provide the FT movement with a set of characteristics upon which to measure the behaviour of other retailers.

$\mathrm{CF}$ is clearly both a pioneer and an early adopter of Fairtrade .This position due to initial low awareness of FT was associated with greater risk, this is in contrast to recent forays by some retailers into FT, solely in response to consumer demand. The success of CF strategy to mainstream fair trade has been underpinned by a focus on social resources and ethical relationship marketing. CF's key media coverage gained by its mainstream position is focused on the relationship with Kuapa Kokoo farmers; challenging the assertion by Low \& Davenport (2005b) that in the UK the FT market leaders sell first and foremost on product quality. This demonstrates the importance of trust and commitment, lending support to Murphy's et al (2007) proposition that relationship marketing has an ethical basis. The venture with Divine Chocolate emphasises the intangibles such as relationships and networks and therefore means CF could be better positioned than its larger supermarket rivals to take advantage of the new dominant logic of marketing (Vargo and Lusch 2004). This is because CF uses more operant resources to co-create value between producers, retailers and consumers. This could be of interest to the wider social enterprise sector.

The success of Fairtrade at CF tends to support Strong $(1996,1997)$ who called for the development of FT brands to communicate the human element of sustainability. The social resources of ethical and social commitments and the structural connections with partners is central to the Co-op brand communications strategy. This paper could also provide an example of connecting branding with 
trust and relationship building (Murphy et al 2007). The relationship with Divine Chocolate is regarded by CF senior management as a new type of relationship based on values other than profit.

The case of CF's Fairtrade strategy shows that a retailer response to FT built on social resources provides Murphy et al (2007) with an example of a company providing an ethical basis to relationship marketing.

\section{Bibliography}

Aaker D .A., Managing Brand Equity, The Free press, New York, NY, 1991.

AC Neilson, UK Grocers Market 12 Weeks Ending 25/03/06 Accessed , 2006 (http://uk.acnielson.com/insights/documents/Insight_Gro_15_apr.pdf)

Andreasen A. R., Marketing Social Change, Jossey Bass, San Francisco, 1995.

Around E., The Fairtrade Towns Initiative: Lessons from Across the Ocean, Oxfam America, Boston, 2006.

Askey H., Knight P., Interviewing for Social Scientists, Sage Publications, London, 1999.

Balfour S., Chairman's Report, The Day Chocolate Company Annual Report 2004-2005, 2006, p. 2.

Barney J. B., Firm Resources and Sustained Competitive Advantage, Journal of Management, 17/1, 1991, pp. 99-120.

http://dx.doi.org/10.1177/014920639101700108

Barratt Brown M., Fair Trade: Reform and Realities in the International Trading Syst., Zed Books, London and New Jersey, 1993.

Berg L. B., Qualitative Research Methods for the Social Sciences, Pearson Education Inc, USA, 2004.

Birchall J., Co-op: the People's Business, Manchester University Press, Manchester and New York, 1994.

Blythman J., Shopped: The Shocking Power of British Supermarkets, HarperCollins UK, 2004.

Bryman A., Quantity and Quality in Social Research, Routledge, London, 1988. http://dx.doi.org/10.4324/9780203410028

Byles K., Every Little Helps, New Consumer Magazine, March/April, 2006, pp. 24-25.

Cookson R., String-Along or Beanfeast?, The Guardian Weekly, 2005, pp. 20-21.

Co-op Fairtrade Marketing Review, internal document, 2007.

Co-operative Food, Co-op Retail Fairtrade Strategy, internal document, Manchester, 2000.

Co-operative Food, The Chocolate Report, a Truly Co-operative Venture, Manchester, 2002.

The Co-operative Group, Coffee, What a Difference a Penny Makes, Manchester, 2003.

Co-operative Food, Co-op Sales Ledger, Manchester, 2006.

Co-operative Food, Fairtrade Strategy Document, Manchester, 2007.

Cowe R., Williams S., Who are the Ethical Consumers?, The Co-operative Bank, 2000.

Crane A., Matten D., Business Ethic, Oxford University Press, Oxford, 2004.

Creyer E. H., The Influence of Firm Behaviour on Purchase Intention: Do Consumers Really Care about Business Ethics?, Journal of Consumer Marketing, vol. 14, n. 6, 1997, pp. 421-432. http://dx.doi.org/10.1108/07363769710185999 
Day Chocolate Company, Divine Gold information leaflet, London, 2002, p. 2.

Day Chocolate Company, Sales Ledger Reports, London, 2006.

Davenport T. H., Prusak L., Working Knowledge: How Organizations Manage What They Know, Harvard Business School Press, Boston, 2000.

Doherty B., Meehan J., Competing on Social Resources: The Case of Day Chocolate Company in the UK Confectionary Sector, Journal of Strategic marketing, vol. 14, n. 4, 2006. http://dx.doi.org/10.1080/09652540600947847

Doherty B., Tranchell S., New Thinking in International Trade? A Case Study of The Day Chocolate Company, Sustainable Development, vol. 13, 2005, pp. 166-176. http://dx.doi.org/10.1002/sd.273

Divine Chocolate Ltd, Divine Chocolate Annual Report, London, 2006.

Duffy R., Fearne A., Hornibrook S., Measuring Distributive And Procedural Justice: an Exploratory Investigation of the Fairness of Retailer-Supplier Relationships in the UK Food Industry, British Food Journal, vol. 105, n. 10, 2003, pp. 682-694. http://dx.doi.org/10.1108/00070700310506236

Eagan J., Relationship Marketing: Exploring Relational Strategies in Marketing, Second Edition, FT Prentice Hall Financial Times, Harlow, 2004.

Eisenhardt K.A., Building Theories from Case Study Research, Academy of Management Review, vol. 14, n. 4, 1989, pp. 532-50. http://dx.doi.org/10.5465/AMR.1989.4308385

Fairtrade Foundation, Fairtrade Foundation Annual Review, London, 2006.

Fairtrade Foundation, Fairtrade Foundation Annual Review, London, 2005.

Financial Times, Ethical Consumption Makes Mark on Branding, London, 2007.

(www.ft.com/cms/s/d54c45ec-c086-11db-995a-000b5df10621.html here on 14th June 2007)

Gill J., Johnson P., Research Methods for Managers, Paul Chapman Publishing, London, 1991.

Glaser B., Theoretical Sensitivity, Sociology Press, Mill Valley, CA, 1978.

Golding K., Peattie, K., In Search of a Golden Blend: Perspectives on the Marketing of Fair Trade Coffee, Sustainable Development, Sust. Dev. 13, 2005, pp. 154-165. http://dx.doi.org/10.1002/sd.274

Gronroos C., Service Management and Marketing: A Customer Relationship Management Approach. John Wiley \& Sons, 2000.

Gummesson E., Relationship Marketing: From 4Ps to 30Rs, Liber-Hermonds, Malmo, 1996.

Gummesson E., Total Relationship Marketing: Rethinking Marketing management from 4Ps to 30Rs, Butterworth Heinemann, Oxford, 1999.

Hamel G., Prahalad C. K., Competing for the Future, Harvard Business School Press, Boston, 1994.

Hira, A., Ferrie, J., Fair Trade: Three Key Challenges for Reaching the Mainstream, Journal of Business Ethics n. 63, 2006, pp. 107-118. http://dx.doi.org/10.1007/s10551-005-3041-8

Hunt Shelby D., Morgan Robert E., The Comparative Advantage Theory of Competition, Journal of Marketing, n. 59, 1995, pp. 1-15. http://dx.doi.org/10.2307/1252069

IFAT, What is Fair trade?, 2006. ( http://www.ifat.org/whatisft.shtml accessed 15/12/06)

Jones E., Twin Trading Ltd Annual Report: Fair Trade at the Crossroads, Twin, London, 2005.

Lafferty B. A., Goldsmith R. E., Newell. S. J., The Dual Credibility Model: The Influence of Corporate and Endorser Credibility on Attitudes and Purchase Intentions, Journal of Marketing Theory and Practice, vol. 10, n. 3, 2002, pp. 1-12. 
Lawrence F., Not on the Label, Penguin Books, London, 2004.

Lofland J., Analytic Ethnography: Features, Failings, and Futures, Journal of Contemporary Ethnography, vol. 24, n. 1, 1996, pp. 30-67. http://dx.doi.org/10.1177/089124195024001002

Low W., Davenport E., Postcards from the Edge: Maintaining the 'Alternative' Character of Fair Trade, Sustainable Development, Sust. Dev. 13, 2005, pp. 143-153. http://dx.doi.org/10.1002/sd.275

Lowe W., Davenport E., Has the Medium (Roast) Become the Message? The Ethics of Marketing Fair Trade in the Mainstream, International Marketing Review, vol. 22, n. 5, 2005, pp. 494-511. http://dx.doi.org/10.1108/02651330510624354

McAllister S., Moving the Dream Mainstream, The Grocer Magazine, May 15 ${ }^{\text {th }}$, 2004, pp. 42-47.

Miles B., Huberman A., Qualitative Data Analysis: An Expanded Sourcebook, Sage Publications, Thousand Oaks, CA, 1994.

Mintel, UK Confectionery Report, Mintel International group Ltd, 2006.

Mintel , UK Confectionery Report, Mintel International group Ltd, 2003.

Mintel , UK Confectionery Report, Mintel International group Ltd, 1999.

Murphy E. P., Laczniak R.G., Wood G. 2007, An Ethical Basis for Relationship Marketing: A Virtue Ethics Perspective, European Journal of Marketing, vol. 41, n. 1 / 2, pp. 37-57. http://dx.doi.org/10.1108/03090560710718102

Murray D., Raynolds L., Alternative Trade in Bananas: Obstacles and Opportunities for Progressive Social Change in the Global Economy, Agriculture and Human values, 17, 2000, pp. 65-74. http://dx.doi.org/10.1023/A:1007628709393

National Consumer Council, What Assures Consumers Report, Accountability, London, 2006.

Nicholls A., Opal C., Fair Trade: Market-Driven Ethical Consumption, Sage Publications, London, 2005.

Nicholls A. J., Strategic Options for Fair Trade Retailing, International Journal of Retail and Distribution Management, vol. 30, n. 1, 2002, pp. 6-17.

http://dx.doi.org/10.1108/09590550210415220

Nonaka I., Takeuchi H., The Knowledge Creating Company: How Japanese Companies Create the Dynamics of Innovation, Oxford University Press, Oxford, 1995.

Ostrander S. A., Surely You're Not in this Just to Be Helpful: Access, Rapport, and Interviews in Three Studies of Elites, Journal of Contemporary Ethnography, vol. 22, n. 1, 1993, pp. 7-27. http://dx.doi.org/10.1177/089124193022001002

Page S., Slater R., Small Producer Participation in Global Food Systems: Policy Opportunities and Constraints, Development Policy Review, vol. 21, n. 5-6, 2003, pp. 641-654.

http://dx.doi.org/10.1111/j.1467-8659.2003.00229.x

Porter M. E., Strategy and the Internet, Harvard Business Review, vol. 73, March 2001, 2001, pp. 6379.

Ransom D., Fair Trade for Sale, New Internationalist, April, 2005, pp. 34-35.

Rayport J., Jaworski B. J., E-commerce, McGraw-Hill, 2002.

Robson C., Real World Research: a Resource for Social Scientists and Practioner Researchers, Blackwell, London, 1997.

Ronchi L., Fair Trade Chocolate Impact Monitoring and Evaluation, University of Sussex, Brighton, 2001.

Seyfang G., Eco-Warriors in the Supermarket? Evaluating the UK Sustainable Consumption Strategy as a Tool for Ecological Citizenship, CSERGE Working paper, EDM, 2004. 
Shaw D., Newholm T., Dickinson R., Consumption as Voting: an Exploration of Consumer Empowerment, European Journal of Marketing, vol. 40, n. 9/10, 2006, pp. 1049-1067. http://dx.doi.org/10.1108/03090560610681005

Srivastava R. K., Fahey L., Christensen H. K., The Resource-Based View and Marketing: the Role of Market-Based Assets in Gaining Competitive Advantage, Journal of Management,n. 27, 2001, pp.777802. http://dx.doi.org/10.1177/014920630102700610

Strong C., Features Contributing to the Growth of Ethical Consumerism - A Preliminary Investigation, Marketing Intelligence and Planning, vol. 14, 1996, pp. 5-9. http://dx.doi.org/10.1108/02634509610127518

Strong C., The Problems of Translating Fair Trade Principles into Consumer Purchase Behaviour, Marketing Intelligence and Planning, vol.15, n. 1, 1997, pp. 32-37. http://dx.doi.org/10.1108/02634509710155642

Teather D., Big Retailers Help Raise Fairtrade Sales by Third, The Guardian, Wednesday June $28^{\text {th }}$, 2006, p. 24

Tesco PLC, Tesco Analyst Report: TESCO PLC Preliminary Results 2006/2007, Tesco, Cheshunt, 2006, p. 10.

The Co-operative Group, Network For Active Members, The Co-operative membership, Manchester, January, 2007.

The Co-operative Group, Coffee, What a Difference a Penny Makes, Manchester, 2003.

The Economist, Voting with Your Trolley: Can You Really Change the World by Buying Certain Foods, vol. 381, Issue 8507, December 9 ${ }^{\text {th, }}$, 2006, pp. 73-75.

Tranchell S., Managing Directors Report, The Day Chocolate Company Annual Report 2004-2005, 2006.

Tiffen P., A Chocolate-Coated Case for Alternative International Business Models, Development in Practice, vol. 12, n. 3-4, 2002, pp. 383-397. http://dx.doi.org/10.1080/0961450220149744

Tiffen P., The Day Chocolate Company- a Commercial Opportunity, London, 1998.

Urry J., Consuming Places, Routledge, London, 1995.

Vargo S. L., Lusch R. F., Evolving to a New Dominant Logic for Marketing, Journal of Marketing, n. 68, 2004, pp. 1-17. http://dx.doi.org/10.1509/jmkg.68.1.1.24036

Yin K. Y., Case Study Research: Design and Methods, Third Edition, Sage Publications, London, 2003. 